\title{
Protective Effect Of Hesperidin And Tiger Nut Against DMBA Carcinogenicity In Female Rats
}

\author{
Soha M. Hamdy ${ }^{1}$, Ola N. Sayed ${ }^{1}$, Abdel Karim M Abdel Latif ${ }^{2}$, Ayman M Abd-Elazeez $^{2}$, \\ Alshimaa M Amin ${ }^{1}$ \\ ${ }^{1}$ Chemistry Department, Faculty of Science, El Fayoum University, El- Fayoum, Egypt. \\ ${ }^{2}$ Zoology Department, , Faculty of Science, El Fayoum University, El- Fayoum, Egypt.
}

\begin{tabular}{ll}
\hline A R T I L INF O & A B T R A T \\
\cline { 2 - 3 } $\begin{array}{l}\text { DMBA, hesperidin, tiger } \\
\text { nut, breast cancer, }\end{array}$ & $\begin{array}{l}\text { Nutritional studies recommend the regular consumption } \\
\text { of fruits and vegetables to favor a healthy quality of life. } \\
\text { Histopathology. }\end{array}$ \\
This study was carried out to evaluate the efficacy of \\
hesperidin and tiger nut against the carcinogenic activity \\
of DMBA in female rats. 72 adult Sprague Dawley female \\
rats were divided equally into six groups: control group \\
(I); hesperidin (HES) treated group (II); tiger nut (TN) \\
treated group (III); DMBA treated group (IV); HES- \\
DMBA treated group (V); and TN-DMBA treated group \\
(VI). There was a significant increase in the levels of \\
serum total sialic acid (TSA), progesterone (Prog) and \\
estradiol (E2), and significant decreases of body weights \\
and reduced glutathione (GSH) level and superoxide \\
dismutase (SOD), catalase (CAT) and glutathione \\
peroxidase (GSH-Px) activities of DMBA treated group \\
compared with the control. Histopathological \\
observations of mammary gland showed that only female \\
rats of DMBA and TN-DMBA treated groups showed \\
breast cancer, while there was no evidence of malignancy \\
in HES-DMBA treated group. In conclusion, our results \\
suggested that supplementation of a diet with hesperidin \\
provided antioxidant defense with chemoprotective \\
activity more significant than tiger nut against the toxicity \\
of DMBA in breast tissue. \\
@ 2016 Publisher All rights reserved.
\end{tabular}

INTRODUCTION

7, 12-Dimethylbenz (a) anthracene is a polycyclic aromatic hydrocarbon $(\mathrm{PAH})$ produced during the incomplete combustion of carbon-containing compounds [1], and predominantly found in tobacco smoke, woodsmoke and motor vehicle exhaust emissions [2]. It is an immunosuppressorand a powerful organspecific laboratory carcinogen $[3,4]$. The main target sites for the potent carcinogenicity of DMBA are the skin and the mammary gland [5]. It has been reported that DMBA induces substantive nephrotoxicity that is characterized by 
renal tubular necrosis, increased number of lysosomes, dilated mitochondria and chromatin condensation in the nucleus $[6,7]$.

Hesperidin (4́-methoxy-7-Orutinosyl-30,5dihydroxyflavanone), a naturally occurring flavanone glycoside, is predominantly found in citrus fruits [8]. It has several biological functions such as anti-inflammatory effects [9], prostaglandin-synthesis inhibition, neuroprotective [10] and modulation of drug-metabolizing enzymes and it does not present toxicity [11]. It exhibit antioxidative properties by several different mechanisms, such as scavenging of free radicals, chelation of metal ions such as iron and copper which are of major importance for the initiation radical reactions, inhibition of enzymes responsible for free radical generation and facilitation endogenous antioxidative defense system [8,12,13,].Also, dietary hesperidin exerts anticarcinogenic actions in the tongue, colon, esophagus, and urinary bladder in rat models of carcinogenesis [14-16].

Tiger nut tubers

(Cyperusesculentus) are edible, with a slightly sweet and nutty flavor. The tubers are used as a foodstuff, particularly in Africa, where it's an important food crop with certain tribes. Tiger nuts have excellent nutritional qualities with a fat composition similar to olives [17] and they are gluten and cholesterol free[18]. Tiger nuts are rich in vitamins $\mathrm{E}$ and $\mathrm{C}$ and rich in minerals such as phosphorous, potassium, calcium, magnesium and iron which necessary for bones, tissue repair, muscles, blood stream, body growth and development [19]. Also they contain high percentage of alkaloids, saponins and tannins which are known to have antimicrobial activity, as well as other physiological activities [20]. Moreover, they exhibit anti-inflammatory properties upon inflammation, and immunostimulatory effects [21].
The objective of the present study is to evaluate the efficacy of hesperidin and tiger nut in modulation of oxidative stress, tumorigenicity and endocrine derangement in rats treated with DMBA. Histological examinations of the breast tissue were assessed to highlight the protective effects of these natural products.

\section{Materials and methods}

Healthy adult female virgin albino rats (Sprague dawley) $(70 \pm 10) \mathrm{g}$, average 6 weeks old, purchased from the Egyptian Holding Company for Biological Products and Vaccines (Cairo, Egypt) were used as experimental animals. The animals were maintained under standard conditions of light, ventilation, temperature, and humidity and allowed to free access to standard pellet diet and tap water. All animal procedures were carried out in accordance with theEthics Committee of the National Research Centre conformed to the "Guide for the care anduse of Laboratory Animals" published by the US National Institutes of Health (NIHpublication No. 85-23, 1996).

\section{Animal groups}

After an acclimation period of 2 weeks, the rats were randomly divided into 6 groups (12 rats/ group). Group I: control; Group II: rats received HES $(50 \mathrm{mg} / \mathrm{Kg} /$ day $)$ via oral gavages during the experimental period [22]; GroupIII: rats fed on a standard diet mixed with $25 \%$ whole powder of tiger nut,TN [21]; Group IV: DMBA treated group were received 10 mg DMBA /rat [5] via oral gavages at 1 week intervals on days 15, 22, and 29; Group V: rats treated with HES + DMBA where rats were received HES $(50 \mathrm{mg} / \mathrm{Kg} /$ day $)$ during 14 successive days before treating with neoplastic agent and during 105 days after treatment; and Group VI: rats treated with TN + DMBA where rats were received TN (25\% of diet) during 14 successive days before treating with neoplastic agent and during 105 days after treatment.

Animals were sacrificed, under anesthesia of ether, after 90 days post the 
last dose of DMBA administration, and blood was collected by heart puncture and centrifuged at $3000 \mathrm{rpm}$ for 15 minutes to separate the serum and stored at $-20{ }^{\circ} \mathrm{C}$. Serum was used for the determination of total sialic acid (TSA) as markers for tumorigenicity, progesterone and estradiol as markers of endocrine derangement, protein carbonyl (CO), malondialdhyde (MDA) as markers for oxidative stress and the level of reduced glutathione (GSH), superoxide dismutase (SOD), glutathione peroxidase (GSH-Px) and catalase (CAT) activities as markers for antioxidant status. Mammary, liver and kidney tissues of each animal were excised and preserved in $10 \%$ neutral buffer formalin for histopathological examination.

\section{Biochemical analysis}

Tumorigenicity Biomarkers assays: Assay of TSA, TSA was determined according to the method described by Plucinskyet al. [23].

Hormonal assays: ELISA procedure was used for quantitative determination of Estradiol (E2) concentration in rat serum using a kit purchased from Sigma Chemical Company (St Louis, MO, USA) according to Tietz[24] and also progesterone using a kit purchased from Sigma Chemical Company (St Louis, MO, USA) according to Tietz [25].

Oxidative stress biomarkers assays: Lipid peroxidation was evaluated by measuring MDA levels according to the method of Yoshioka et al. [26]. Protein oxidation was evaluated by measuring protein carbonyl (CO) content as described by Levine et al. [27]. The activity of SOD was determined according to the method of Minami and Yoshikawa [28]. The activity of CAT was determined according to the method of Aebi[29]. The activity of GSH-Px was determined according to the method of Paglia and Valentine [30]. Reduced glutathione content was estimated according to Beutleret al. [31].

\section{Histopathological investigation:}

The mammary tissues were taken and fixed in $10 \%$ buffered formalin, embedded in pure paraffin wax (melting point of $58^{\circ} \mathrm{C}$ ) and then mounted into blocks and left at $4{ }^{\circ} \mathrm{C}$ until the time of use. The paraffin blocks were sectioned on the microtome at thickness of $5 \mathrm{~mm}$ and mounted on clean glass slides then left in the oven at $40^{\circ} \mathrm{C}$ for dryness. The slides were deparafinized in xylol then immersed in descending series of alcohol concentration (90-50\%). The ordinary hematoxylin and eosin stain were used [32].

\section{Statistical analysis:}

The Statistical Package for the Social Sciences (SPSS/PC) computer program was used for statistical analysis of the results. Data were analyzed using one way analysis of variance (ANOVA) followed by Post Hoc to determine significant differences between means. The data were expressed as mean \pm standard deviation (SD). Differences were considered significant at $P \leq 0.05$.

\section{Results}

\section{Biochemical Results}

No rats died in groups I,II and III, 6 of 12 rats died in Group IV. In Group V, 3 of 12 rats died, while in Group VI, 5 of 12 rats died. There was an increase in the body weight in all groups at the time of killing compared to at the start of experiment, with percentage changes $69.3 \%, 122 \%, 87.4 \%, 18.7 \%, 57.6 \%$ and $38.5 \%$ for groups I-VI, respectively, (Table 1). At the end of the experiment, groups IV, V and VI were significantly decreased in the body weight compared to control group. There was a significant increase in the body weight on rats treated with HES and DMBA (Group V) compared with rats treated with DMBA only (Group IV). On the other hand, there was no significant change in the body weight between rats treated with $\mathrm{TN}$ and DMBA (Group IV) and rats in group IV (Table 1). Table 2 showing that serum levels of TSA, progesterone and estradiol were significantly increased in groups IVVI when compared with control (Group I). There were no significant changes in the 
levels of TSA, progesterone and estradiol between group IV and group VI, while they decreased significantly in Group V when compared to DMBA-treated group (Group IV).

Serum levels of both protein carbonyl and MDA were significantly increased in groups IV-VI when compared with control rats. They were significantly decreased in group $\mathrm{V}$ with $p$ value $<0.001$ when compared to DMBA-treated group, while there were no significant differences between groups IV and VI. Serum SOD, CAT, GSH-Px activities and the level of GSH were significantly decreased in groups IV-VI when compared to control group, while they were significantly increased in group $\mathrm{V}$ when compared to DMBA-treated group (Table 3) and there were no significant differences between groups IV and VI.

\section{Histopathological Examinations of Rat}

\section{Mammary Glands}

Histopathological examinations of the control mammary glands showed that mammary glands were made up of scattered tubular branching ducts and glandular alveoli; both lined by one to two layers of low cuboidal epithelium and had well defined lumen. The epithelium rests on a basement membrane was surrounded by a layer of myoepithelial cells. The lumen of the alveoli of the mammary glands appeared clear without any cell debris or any secretion. The breast tissue of female rat of group II and III is more or less similar to those of control group (Fig. 1A,B\&C).

In DMBA-treated group (group IV), the studied paraffin sections showed well developed breast carcinoma with wide areas of necrosis and tumor breakdown indicating the high proliferation of tumor cells with surrounding residual viable proliferating malignant cells (Fig. 2A). The cell showed nucleomegaly, pleomorphism, increased mitosis and moderate overall anaplasia. The mammary glands also showed atypical proliferative changes characterized by a progressive elongation of ducts as well as proliferation and expansion of the terminal lobular units with compression of the surrounding fat pad, progressing to cystic papillary carcinoma (Fig. 2B).

Female rat protected with HES against the carcinogenicity of DMBA showed no appearance of malignancy with very mild histopathological alterations as shown in figure 3. In other instances hyperplasia still present, vacuolization in many cells was commonly occurred and decreased numbers of alveoli with hypertrophic and hyperplastic epithelium forming small lobules of glandular tissue surrounding ducts. While, the mammary alveoli of group VI exhibited well defined mass of breast carcinoma that surrounded by fibrous tissue and embedded in adipose connective tissue with adjacent enlarged activated lymph node. (Fig. 4).

\section{Discussion}

It is vital to enhance our understanding of the role of naturally occurring antioxidants in cancer prevention and their possible use in intervention trials for the prevention of cancer in humans. DMBA-induced experimental carcinogenesis might therefore be used as an ideal model to study the chemopreventive potential of natural entities [33]. Frequent production of ROS cause free radicals and electrophiles mediated oxidative stress favouring the progression of carcinogenesis. These highly reactive species causes oxidative modification of DNA, proteins, lipids and small intracellular molecules [34]. In our study, we administered DMBA at the age of 56 days due to susceptibility of the mammary gland to DMBA carcinogenesis is strongly age-dependent, being maximal when the drug is administered to rats between the age of 45 and 60 days, the age of the beginning of sexual maturity[35]. 
In the present study, the total body weights of the DMBA and TN-DMBA treated groups were declined with $p$ value: $<0.001$ when compared to control group. Our findings desperately agree with the previous findings of Cheng $\boldsymbol{e t}$ al. [36] and Anbuselvam et al. [37] who reported that tumor growth elicited marked loss of body weight in animals with breast cancer. The decreased body weight might be due to the changes in energy metabolism during tumor formation. It was well known that in cancer condition excessive energy expenditure of the host, ultimately contributing to mechanisms that promote weight loss [38]. Additionally, our results were in accordance with the result of Davis and Kuttan[39] and Moselhy et al. [40] who stated that the generation of ROS and the peroxidation of membrane lipids were associated with the initiation and progression of cancer affecting the normal biochemical process which further leading to the reduction of body weight.

In our results, upon treatment with each of hesperidin and tiger nut, the body weights increased significantly in HESDMBA treated group versus DMBA treated group $(p=0.001)$ while there was no significant difference between DMBA and TN-DMBA treated groups. Additionally, there was a significant increase in HES-DMBA treated group with $p$ value: 0.029 when compared to TNDMBA treated group.

Our findings of the increased body weights in the groups protected with hesperidin were in parallel with the studies ofKamaraj et al.[41] and Al-Jasabi and Abdullah [42] who reported that while the total body weight was decreased in tumorbearing mice (lung cancer); pre and post treatment with hesperidin resulted in a significant increase in the body weight. Also, Nandakumaret al. [43] reported that daily oral administration of hesperidin to breast cancer bearing rats showed a significant improvement in the body weight when compared with cancer bearing animals and this might be due the antioxidant activity exhibited by the bioflavonoid hesperidin.

In our study, serum level of total sialic acid (TSA) significantly elevated in the DMBA and TN-DMBA treated groups $(p<0.001)$ versus control group, and there was no significant difference between TNDMBA and DMBA treated groups. These findings were in agreement with our histopathological results that showed the formation of breast cancer in these two groups. The increased TSA levels here were similar with the findings of Raval $\boldsymbol{e t}$ al. [44], Hamdy et al. [45] and Oto et al. [46]who reported that administration of DMBA increased the level of serum TSA, which is a sensitive marker for detecting the toxic effects of DMBA and this increase might be explained by enhanced activity of sialidase enzyme in breast cancer $[47,48]$.

Conversely, our results showed a highly significant reduction in serum TSA level in HES-DMBA treated group $(p<0.001)$ when compared with DMBA and TN-DMBA-treated groups. Our findings were in agreement with the results obtained by Nandakumar et al. [43,49] who reported that administration of hesperidin controlled the nucleic acid biosynthesis and exhibited the tumor inhibitory effect during the treatment of breast cancer induced by DMBA toxicity. Moreover, our results showed a significantly increase $(P=0.001)$ in the levels of serum TSA in HES-DMBA group as compared with the control group (no malignancy was recorded in our histopathological results). This increase in the TSA level might be due to the presence of inflammation in any part of animal body and not due to breast cancer. In this respect,Suer and Kazwzoglu[50]and Hamzah et al. [51] reported that the biochemical alternation in total sialic acid concentrations was associated positively with the presence of inflammation and could be suggested as a potential inflammatory marker for several diseases including myocardial infarction, 
inflammatory disease and bacterial infections.

Moreover, there was a significant increase in the estradiol and progesterone levels in DMBA and TN-DMBA treated groups $(p<0.001)$ when compared with the control. Similar results were observed by Hamdyet al. [45] who reported that the injection of single dose of $(10 \mathrm{mg} / \mathrm{rat})$ DMBA resulted in a significant increase in the marker levels of endocrine derangement, prolactin and estradiol. In this respect, Vondrácek et al. [52] and Hussein and Ismael [53] proved that the endocrine derangement that occurred in the human breast had an important impact on the development of breast cancer.

In the present study, hesperidin supplementation in HES-DMBA treated group significantly decreased serum levels of estradiol and progesterone $(p<0.001)$ when compared to DMBA and TN-DMBA treated groups, while there were no significant changes in their levels between DMBA and TN-DMBA treated groups.

Our study showed elevated levels of serum MDA and CO in DMBA and TN-DMBA treated groups when compared to the control $(p<0.001)$ and there was no significant difference in their levels between DMBA and TN-DMBA treated groups. This was consistent with previous reports that DMBA induced critical oxidative damage in the liver in vivo [54,55]. Moreover, our results were in agreement with the data obtained byTabaczaret al.[56] who reported that the development of DMBA-induced mammary tumors in rats was associated with a significant increase in protein and lipid oxidation markers in blood plasma. Furthermore, Rajakumar et al.[57] reported that the levels of MDA and lipid hydroperoxides in plasma and mammary tissues were significantly increased in DMBA-induced breast cancer rats via the overproduction and diffusion of free radicals from damaged tumor tissues compared with normal rats. $\begin{array}{ccc}\text { Our results indicated that } \\ \text { hesperidin } & \text { supplementation }\end{array}$ significantly decreased the levels of MDA in HES-DMBA treated group $(p<0.001)$ when compared with DMBA and TNDMBA treated groups. Additionally, serum $\mathrm{CO}$ level decreased significantly in HES-DMBA group $(p<0.001)$ versus DMBA and TN-DMBA treated groups. Our results were in agreement with Wang et al. [58] who reported that chronic administration of hesperidin attenuated oxidative damage by decreasing lipid peroxidation, restoring mitochondrial enzyme activity, and increasing oxidative defense. Moreover, Javed et al. [59]reported that pretreatment with hesperidin attenuated the elevated level of MDA content in streptozotocin injected mice.

The enzymatic antioxidants SOD, CAT and GSH-Px and GSH content play a vital role during the process of scavenging reactive oxygen [60]. Our results demonstrated significant decreases of SOD, CAT and GSH-Px activities and GSH content in DMBA and TN-DMBA treated animals with $p$ value: $<0.001$ when compared to control group and there was no significant difference between DMBA and TN-DMBA treated animals. The decrease of SOD, CAT and GSH-Px activities and GSH content was probably might result from their increased utilization to neutralize the excess of free radicals generated in the body after DMBA induction and might indicated the weak free radical defense system against oxidative stress [37]. The observed lower level of glutathione in mammary carcinoma rats might be resulted in enhanced lipid peroxidation and excess utilization of this antioxidant for tumor cell proliferation, which was in line with earlier reports [61].

In our results, there was statistically significant increase in serum GSH level and SOD, CAT and GSH-Px activities in HES-DMBA treated group with $p$ value $<0.001$ when compared with 
both DMBA and TN-DMBA treated groups, while there were no significant differences between TN-DMBA and DMBA treated groups for these levels. The improvement in oxidant/antioxidant status might support the role of HES in scavenging free radicals. Similarlly, Bentli et al. [62] reported that the use of HES in combination with 2,3,7,8Tetrachlorodibenzo-p-dioxin, minimized its toxicity as revealed by increased antioxidant enzyme activity (SOD, CAT) and GSH levels. Moreover, Khan and Parvez[63] reported that hesperidin treatment attenuated the altered levels of oxidative stress and neurotoxicity biomarkers against oxidative damage in cadmium treated rat model.

Our histopathological results showed that administration of three successive doses of DMBA (10 $\mathrm{mg} / \mathrm{rat} /$ week) induced breast carcinoma in only DMBA and TN-DMBA treated animals. The studied paraffin sections of DMBA treated animals showed well developed breast carcinoma with wide areas of necrosis and atypical proliferative changes characterized by a progressive elongation of ducts as well as proliferation and expansion of the terminal lobular units with compression of the surrounding fat pad, progressing to cystic papillary carcinoma. The cell showed nucleomegaly, pleomorphism, increased mitosis and moderate overall anaplasia. These findings agree with our previously reported higher breast cancer markers (TSA, estradiol and progesterone).

Similar observations were obtained by Pandi et al. [64] who reported that administration of DMBA caused rat mammary gland carcinoma characterized by extensive solid areas, tumor necrosis exhibiting the appearance of a comedocarcinoma and clumping of chromatids. Also, Bishayeea and Mandal [65]investigated that administration of DMBA manifested ductal hyperplasia, marked alteration and enlargement of the alveolus, uniformly neoplastic ductal epithelial cells with nuclear polemorphism and growth variation of epithelial cells in nuclear size and irregular chromatin. Moreover, Minari and Okeke[66] showed that the intragastrically treatment of 20 $\mathrm{mg} / \mathrm{ml} /$ week of DMBA by gavage for six weeks induced lobular alveolar hyperplasia, fibroadenomatoid hyperplasia in breast tissues suggesting a neoplastic transformation which is an indication of DMBA-induced cell proliferation.

On the other hand, no malignancy appeared in animals of HES-DMBA treated group. Protection of DMBA treated animals by HES administration $(50 \mathrm{mg} / \mathrm{kg}$ body weight) provided a significant improvement with very mild histopathological alterations such as hyperplasia; vacuolization in many cells and decreased numbers of alveoli with hypertrophic and hyperplastic epithelium. Our results agree with the results obtained by Nandakumar et $\boldsymbol{a l}$.[49] who reported that administration of hesperidin after mammary cancer induction by a single dose of $20 \mathrm{mg} / \mathrm{kg}$ DMBA showed that almost normal cytoplasm with undisturbed, protected number of mitochondria and reduced neoplastically transformed cells, which inevitably proved the antineoplastic activity of hesperidin. Moreover, it was shown that HES modifies the production of cytokines and enzymes that are involved in inflammation which play a crucial role in the anti-cancer effects of HES [67].

As mentioned above the administration of tiger nut didn't prevent the appearance of the breast cancer in the female rats of TN-DMBA treated group but in less number of animals and with less degree where a well-defined mass of breast carcinoma that surrounded by fibrous tissue with adjacent enlarged activated lymph node were noted. The activation of lymph node and fibrosis around the cancerous tissue in TN-DMBA group might be due to the nutritional benefits of tiger nut on the immune cell. In this respect, Hassan [68] showed that tiger 
nut exhibits selective effects on $\mathrm{T}$ lymphocytes, which inhibits the proliferation of the inflammatory lymphocytes and increases the proliferation of naive lymphocytes. Moreover, tiger nut is a good source of fatty hydroxamic acid. Suberoylanilidehydroxamic acid, specific derivatives of hydroxamic acid, has been reported to be a potent inhibitor of histone deacetylases, and possesses anticancer and apoptosis effect against several tumor types [69,70]. Furthermore, fibrosis is a common, persistent and potentially debilitating complication of chemotherapy and radiation regimens used for the treatment of cancer [71]. Breast fibrosis is a common occurrence following anticancer radiation therapy [72].

In conclusion, the present study proved that the oxidative stress resulted from DMBA played an important role in inducing breast cancer. The histopathological changes that occurred in breast tissue of female rats as well as the disturbance of the biochemical parameters recorded in animals treated with DMBA were counteracted after HES administration causing a protective effect for DMBA toxicity. Here, hesperidin was more potent as chemoprotective agent than tiger nut.

\section{References:}

1. Lim, V. S.; Korourian, S.; Todorova, V.K.; Kaufmann, Y.; Klimberg V.S. (2009): Glutamine prevents DMBA-induced squamous cell cancer, Oral Oncology; 45: 148-155.

2. Burchiel, S.W.; Lauer, F.T.; Dunaway， S.L.; Zawadzki，J.; McDonald, J.D.; Reed, M.D. (2005): Hardwood smoke alters murine splenic $\mathrm{T}$ cell responses to mitogens following a 6-month whole body inhalation exposure, Toxicol. Appl. Pharmacol; 202: 229-236.

3. Miyata, M.; Furukawa, M.; Takahashi, K.; Gonzalez, F.J.; Yamazoe, Y. (2001): Mechanism of $7,12-$ dimethylbenz[a]anthraceneinduced immunotoxicity: role of metabolic activation at the target organ, Jpn. J. Pharmacol.; 86(3):302-9.

\section{Buters, J.; Quintanilla-Martinez,} L.; Schober, W.; Soballa, V.J.; Hintermair, J.; Wolff, T.; Gonzalez, F.J.; Greim, H. (2003): CYP1B1 determines susceptibility to low doses of 7,12dimethylbenz[a]anthraceneinduced ovarian cancers in mice: correlation of CYP1B1-mediated DNA adducts with carcinogenicity, Carcinogenesis; 24: 327- 334.

5. Girolami, F.; Abbadessa, G.;Racca, S.; Spaccamiglio, A.; Piccione, F.; Dacasto, M.; Carletti, M.; Gardini, G.; Di Carlo, F.; Nebbia, C. (2008): Time-dependent acetylsalicylic acid effects on liver CYP1A and antioxidant enzymes in a rat model of 7,12-dimethylbenzanthracene (DMBA)-induced mammary carcinogenesis, Toxicol Lett.;181(2):87-92.

6. Ozturk, F.; Ozturk, I.C.; Batcioglu, K.; Vardi, N. (2006): The effect of melatonin on 7,12dimethylbenz[a]anthracene injury in comparison with vitamin $\mathrm{E}+$ selenium in mouse kidneys, 
Fundam. Clin. Pharmacol.; 20 (4):359-364.

7. Yehia, M.A.H.; Zoheir, A.M.H.Y.; Awatef, M.A.U. (2007): Histochemical and ultrastructural studies on rat proximal convoluted tubules under the effect of 7,12dimethylbenz[a]anthracene and tamoxifen treatment, Egypt. J. Histol.; 30(1):465-472.

8. Yang, H.L.; Chen, S.C.; Kumar, K.J.S.; Yu, K.N.; Chao, D.L.; Tsai, S.Y.; Hou, Y.C.; Hseu, Y.C. (2012): Antioxidant and antiinflammatory potential of hesperetin metabolites obtained from Hesperitin-administered rat serum: na ex vivo approach, $J$. Agric. Food Chem.; 60:522-532.

9. Emim, J.A.; Oliveira, A.B.; Lapa, A.J. (1994): Pharmacological evaluation of the anti-inflammatory activity of a citrus bioflavonoid, hesperidin, and the isoflavonoids, duartin and claussequinone, in rats and mice, $J$. Pharm. Pharmacol; 46 (2): 118-22.

10. Hwang, S.L.; Yen, G.C. (2008): Neuroprotective effects of the citrus flavanones against $\mathrm{H}_{2} \mathrm{O}_{2}$ induced cytotoxicity in PC12 cells; J. Agric. Food Chem.; 56: 859864.

11. Garg, A.; Garg, S.; Zaneveld, L.J.; Singla, A.K. (2001): Chemistry and pharmacology of the Citrus bioflavonoid hesperidin. Phytother Res.; 15: 655-669.

12. Cai, Y.Z.; Sun, M.; Xing, J.; Luo, Q.; Corke, H. (2006): Structure- radical scavenging activity relationships of phenolic compounds from traditional Chinese medicinal plants, Life Sci.; 78:2872-2888.

13. Ahmad, S.T.; Arjumand, W.; Nafees, S.; Seth, A.; Ali, N.; Rashid, S.; Sultana, S. (2012): Hesperidin alleviates acetaminophen induced toxicity in Wistar rats by abrogation of oxidative stress, apopotosis and inflammation, Toxicol. Lett.; 205:149-161.

14. Tanaka, T.; Kohno, H.; Murakami, M.; Shimada, R.; Kagami, S.; Sumida, T.; Azuma, Y.; Ogawa, H. (2000): Suppression of azoxymethaneinduced colon carcinogenesis in male F344 rats by mandarin juices rich in beta-cryptoxanthin and hesperidin, Int. J. Cancer; 88:146150.

15. Cho, J. (2006): Antioxidant and neuroprotective effects of hesperidin and its aglyconehesperetin. Arch Pharm Res.;29(8):699-706.

16. Lee, K.H.; Yeh, M.H.; Kao, S.T.; Hung, C.M.; Yeh, C.C. (2010): The inhibitory effect of hesperidin on tumor cell invasiveness occurs via suppression of activator protein 1 and nuclear factor- $\mathrm{kB}$ in human hepatocellular carcinoma cells,Toxicol. Lett.; 194:42-49.

17. Coşkuner, Y.; Ercan, R.; Karababa, E.; Nazlican, A.N. (2002): Physical and chemical properties of chufa (Cyperusesculentus L) tubers 
grown in the Çukurova region of Turkey, J Sci Food Agri.; 82:62531.

18. Gambo, A.; Da'u, A. (2014): Tiger nut (cyperusesculentus): composition, products, uses and health benefits - a review, Bayero Journal of Pure and Applied Sciences; 7(1): $56-61$.

19. Belewu, M.A.; Belewu, K.Y. (2007): Comparative physicochemical evaluation of tigernut, soybean and coconut milk sources, Intl J Agric Biol.; 5:785-7.

20. Evans, N.S. (2005.): Trease and Evans. Pharmocognosy, $15^{\text {th }}$ Edn, Elsevier, India; 1-24.

21. Salem, L.M.; Zommara, M.; Imaizumi, K. (2005): Dietary supplementation with Cyperusesculentus L (tigernut) tubers attenuated atherosclerotic lesion in apolip-oprotein $\mathrm{E}$ knockout mouse associated with inhibition of inflammatory cell responses, Am. J. Immuno.; 1 (1): 60-67.

22. Hosseinimehr, S.J.; Nemati, A. (2006): Radio-protective effects of hesperidin against gamma irradiation in mouse bone marrow cells, Br. J. Radiol.; 79:415-418.

23. Plucinsky, M.C.; Riley, W.M.; Prorok, J.J.; Alhadeff, J.A. (1986): Total and lipid-associated serum sialic acid levels in cancer patients with different primary sites and differing degrees of metastatic involvement, Cancer; 58(12): 2680-2685.
24. Tietz, N.W. (1995 a): Clinical guide to laboratory tests. $3^{\text {rd }}$ ed. Philadelphia: WB Saunders, 216217.

25. Tietz, N.W. (1995 b): Clinical Guide to Laboratory Tests, 3rd Edition, W.B. Saunders, Co., Philadelphia, 509-512.

26. Yoshioka, T.; Kawada, K.; Shimada, T.; Mori, M. (1979): Lipid peroxidation in maternal and cord blood and protective mechanism against activated oxygen toxicity in the blood, Am. $J$. Obstet. Gynecol.; 135: 372-376.

27. Levine, R.L.; Garland, D.; Oliver, C.N.; Amici, A.; Climent, I.; Lenz, A.G.; Ahn, B.W.; Shaltiel, S.; Stadtman, E. (1990): Methods Enzymol.; 186: 464-478.

28. Minami, M.; Yoshikawa, H. (1979): A simplified assay method of superoxide dismutase activity for clinical use, ClinChimActa.; 92: 37-42.

29. Aebi，H. (1983): Catalase. In: Bergmeyer H U eds. Methods of Enzymatic Analysis 2nd ed.: 273277 VerlagChemieWeinheim, Germany.

30. Paglia, D.E. and Valentine, W.N. (1967): Studies on the quantitative and qualitative characterization of erythrocyte glutathione peroxidase, Journal of Laboratory and Clinical Medicine; 70:158.

31. Beutler, E.; Duron, O.; Kelly, B.M. (1963): Improved method of the determination of blood glutathione. J Lab Clin Med.; 61(5): 882-888. 
32. Drury, R.A.B.; Wallington, E.A. (1980): Preparation and fixation of tissues in carleton's histological technique. 4th ed.oxford university press; 36-56.

33. Rastogi, S.; Shukla, Y.; Paul, B.N.; Chowdhuri, D.K.; Khanna, S.K.; Das, M. (2007): Protective efect of Ocimum sanctum on 3methyl-cholanthrene, 7,12dimethylbenz(a)anthracene and alatoxin B1 induced skin tumorigenesis in mice, Toxicology and Applied Pharmacology; 224(3):228-240.

34. Banakar, M.C.; Paramasivan, S.K.; Chattopadhyay, M.B.; Datta, S.; Chakraborty, P.; Chatterjee, M.;Kannan, K.; Thygarajan, E. (2004):1-alpha, 25-dihydroxy vitamin D3 prevents DNA damage and restores antioxidant enzymes in rat hepatocarcinogenesis induced by diethylnitrosamine and promoted by phenobarbital. World $J$ Gastroenterol; 10: 1268-1275.

35. Grubbs， C.J.; Juliana， M.M.; Hill, D.L.; Whitaker, L.M. (1986): Suppression by pregnancy of chemically induced preneoplastic cells of the rat mammary gland, Anticancer Research; 6(6): 1395-400.

36. Cheng, J.L.; Futakuchi, M.; Ogawa, K.; Iwata, T.; Kasai, M.; Tokudome, S.; Hirose, M.; Shirai, T. (2003): Dose response study of conjugated fatty acid derived from safflower oil on mammary and colon carcinogenesis pretreated with 7 , 12-dimethylbenz(a)anthracene and 1,2-dimethylhydrazine in female Sprague-Dawley rats, Cancer Lett; 196:161-8.

37. Anbuselvam, C.; Vijayavel, K.; Balasubramanian, M.P. (2007):Protective effect of Operculinaturpethum against 7,12dimethyl benz(a)anthracene induced oxidative stress with reference to breast cancer in experimental rats, ChemBiol Interact.; 168(3):229-36.

38. Tisdales, M.J. (1997): Biology of cachexia. J. Natl. Cancer; 89: 1763-1773.

39. Davis, L.; Kuttan, G. (2001): Effect of Withaniasomnifera on DMBA induced carcinogenesis. $J$. Ethnopharmacol; 75: 165-168.

40. Moselhy, S.S.; Mohamed, A.; Al mslmani, B. (2008):Chemopreventive effect of lycopene alone or with melatonin against the genesis of oxidative stress and mammary tumors induced by $7, \quad 12$ dimethylbenz(a)anthracene in Sprague dawley female rats, $\mathrm{Mol}$ Cell Biochem; 319:175-80.

41. Kamaraj, S.; Ramakrishnan, G.; Anandakumar, P.; Jagan, S.; Devaki, T. (2009): Antioxidant and anticancer efficacy of hesperidin in benzo(a)pyrene induced lung carcinogenesis in mice, Investig. New Drugs; 27: 214-222.

42. Al-Jasabi, S. and Abdullah, M.S. (2013): The role of antioxidant hesperidin in the attenuation of 
lung cancer caused by Benzo[a]pyrene in Balb/c Mice, World Applied Sciences Journal; 22 (8): 1106-1110.

43. Nandakumar, N.; Jayaprakash, R.; Rengarajan, T.; Ramesh, V.; Balasubramanian, M.P. (2011a): Hesperidin, a natural citrus flavonoglycoside, normalizes lipid peroxidation and membrane bound marker enzymes in 7, 12Dimethylbenz (a) anthracene induced experimental breast cancer rats, Biomedicine \& Preventive Nutrition; 1: 255-262.

44. Raval, G.N.; Patel, D.D.; Parekh, L.J.; Patel, J.B.; Shah, M.H.; Patel, P.S. (2003): Evaluation of serum sialic acid, sialyl transferase and sialoproteins in oral cavity cancer. Oral Dis.; 9:119-128.

45. Hamdy, S.M.; Abdel Latif, A.M.; Drees, E.A.; Soliman, S.M. (2011): Prevention of rat breast cancer by genistin and selenium, Toxicology and Industrial Health; 1-12

46. Oto, G.; Ekin, S.; Ozdemir, H.; Levent, A.; Berber, I. (2012): The effect of Plantago major Linnaeus on serum total sialic acid, lipidbound sialic acid, some trace elements and minerals after administration of 7,12dimethylbenz(a)anthracene in rats, ToxicolInd Health; 28(4):334-42.

47. Sonmez, H.; Suer, S.; Gungor, Z.; Baloglu, H.; Kokoglu, E. (1999): Tissue and serum sialidase levels in breast cancer, Cancer Lett.; 136:75-78.
48. Raval, G.N.; Parekh, L.J.; Patel, D.D.; Jha, F.P.; Sainger, R.N.; Patel, P.S. (2004): Clinical usefulness of alterations in sialic acid, sialyltransferase and sialoproteins in breast cancer, Indian Journal of Clinical Biochemistry;19(2):60-71.

49. Nandakumar, N.; Haribabu, L.; Perumal, S.; Balasubramanian, M.B. (2011 b): Therapeutic effect of hesperidin with reference to biotransformation, lysosomal and mitochondrial TCA cycle enzymes against $7,12-$ dimethylbenz(a)anthraceneinduced experimental mammary cellular carcinoma, Biomedicine \& Aging Pathology;1:158-168.

50. Suer, G.S.; Kazwzoglu, C. (2006): Relationship between serum sialic acids, sialic acid-rich inflammation-sensitive proteins and cell damage in patients with acute myocardial infarction, Clin. Chem. Lab. Med.; 44(2):199-206.

51. Hamzah, M.I.; Al-Bayati, M.A.M.; Al-Rubaye, F.G. (2014): Serum sialic acid (total sialic acid and lipid associated sialic Acid), $\beta$ carotene and superoxide dismutase (SOD) levels in Iraqi patients with knee osteoarthritis, Canadian Journal of Pure and Applied Sciences; 8(3):3029-3033.

52. Vondrácek, J.; Kozubík, A.; Machala, M. (2002): Modulation of estrogen receptor-dependent reporter construct activation and G0/G1-S-phase transition by polycyclic aromatic hydrocarbons 
in human breast carcinoma MCF-7 cells. Toxicol Sci.; 70(2):193-201.

53. Hussein, M.R.; Ismael, H.H. (2004): Alterations of $\mathrm{p} 53, \mathrm{Bcl}-2$, and $\mathrm{hMSH} 2$ protein expression in the normal breast, benign proliferative breast disease, in situ and infiltrating ductal breast carcinomas in the upper Egypt, Cancer BiolTher.; 3(10):983-8.

\section{Letchoumy， P.V.; Chandra Mohan, K.V.;}

Kumaraguruparan, R.; Hara, Y.; Nagini, S. (2006): Black tea polyphenols protect against 7,12dimethylbenz[a]anthracene-

induced hamster buccal pouch carcinogenesis, Oncol Res.; 16: 167-178.

55. Manikandan, P.; Murugan, R.S.; Abbas, H.; Abraham, S.K.; Nagini, S. (2007): Ocimum sanctum Linn. (Holy Basil) ethanolic leaf extract protects against $7, \quad 12$ dimethylbenz(a)anthraceneinduced genotoxicity, oxidative stress, and imbalance in xenobiotic-metabolizing enzymes, J Med Food.; 10(3):495-502.

56. Tabaczar, S.; Pieniążek, A.; Czepas, J.; Piasecka-Zelga, J.; Gwoździński, K.; Koceva-Chyła, A. (2013): Quercetin attenuates oxidative stress in the blood plasma of rats bearing DMBA-induced mammary cancer and treated with a combination of doxorubicin and docetaxel, Gen Physiol Biophys.;32(4):535-43.

57. Rajakumar, T.; Pugalendhi, P.; Thilagavathi, S. (2015): Dose response chemopreventive potential of allyl isothiocyanate against 7,12dimethylbenz(a)anthracene induced mammary carcinogenesis in female Sprague-Dawley rats, ChemicoBiological Interactions; 231:3543.

58. Wang, D.; Liu, L.; Zhu, X.; Wu, W.; Wang, Y. (2014): Hesperidin alleviates cognitive impairment, mitochondrial dysfunction and oxidative stress in a mouse model of Alzheimer's disease, Cell. Mol. Neurobiol.; 34:1209-1221.

59. Javed, H.; Vaibhav, K.; Ahmed, M.E.; Khan, A.; Tabassuma, R.; Safhi, M.M.; Islam, F. (2015): Effect of hesperidin on neurobehavioral,

neuroinflammation, oxidative stress and lipid alteration in intracerebroventricularstreptozotoc in induced cognitive impairment in mice, Journal of the Neurological Sciences; 348:51-59.

60. Lone, A.A.; Ganai, S.A.; Ahanger, R.A.; Bhat, H.A.; Bhat, T.A.; Imtiyaz A. Wani, I.A.(2013): Free radicals and antioxidants: Myths, facts and mysteries, African Journal of Pure and Applied Chemistry;7(3): 91113.

\section{Purushothaman,}

A.l.;Nandhakumar,

E.; Sachdanandam, P. (2013): Phytochemical analysis and anticancer capacity of Shemamruthaa, a herbal formulation against DMBAinduced mammary carcinoma in 
rats, Asian Pac J Trop Med.; 6(12):925-33.

62. Bentli, R.; Ciftci, O.; Cetin, A.; Unlu, M.; Basak, N.; Cay, M. (2013): Oral administration of hesperidin, a citrus flavonone, in rats counteracts the oxidative stress, the inflammatory cytokine production, and the hepatotoxicity induced by the ingestion of $2,3,7,8$ tetrachlorodibenzo-p-dioxin

(TCDD), Eur Cytokine Netw.; 24(2):91-6.

63. Khan, M.H.A; Parvez, S. (2015): Hesperidin ameliorates heavy metal induced toxicity mediated by oxidative stress in brain of Wistar rats, Journal of Trace Elements in Medicine and Biology; 31:53-60.

64. Pandi, M;.Rajapriya, P.; Suresh, G.; Ravichandran, N.; Manikandan, R.; Thiagarajan, R.; Muthumary J. (2011): A fungal taxol from Botryodiplodiatheobromae Pat., attenuates 7,12 dimethyl benz(a)anthracene (DMBA)induced biochemical changes during mammary gland carcinogenesis, Biomedicine \& Preventive Nutrition;1:95-102.

65. Bishayeea, A.; Mandal, A. (2014): Trianthemaportulacastrum Linn. exerts chemoprevention of 7,12-dimethylbenz(a)anthraceneinduced mammary tumorigenesis in rats. Mutat Res.; 768:107-18.

66. Minari, J.B.; Okeke, U. (2014):Chemopreventive effect of Annona muricata on DMBAinduced cell proliferation in the breast tissues of female albino mice, Egypt J Med Hum Genet.; 15: 327-334.

67. Roohbakhsh, A.; Parhiz, H.; Soltani, F.; Rezaee, R.; Iranshahi, M. (2015): Molecular mechanisms behind the biological effects of hesperidin and hesperetin for the prevention of cancer and cardiovascular diseases, Life Sci.;124:64-74.

68. Hassan, H.A. (2007): Effect of dietary supplementation with tigernut tubers on streptozotocininduced diabetic rats, The Egyptian Journal of Hospital Medicine; 29: 475- 485 .

69. Garcia-Manero, G.; Yang, H.; Bueso-Ramos, C.; Ferrajoli, A.; Cortes, J.; Wierda, W.G.; Faderl, S.; Koller, C.; Morris, G.; Rosner, G.; Loboda, A.; Fantin, V.R.; Randolph, S.S.; Hardwick, J.S.; Reilly, J.F.; Chen, C.; Ricker, J.L.; Secrist, J.P.; Richon, V.M.; Frankel, S.R.; Kantarjian, H.M. (2008): Phase 1 study of the histone deacetylase inhibitor vorinostat (suberoylanilidehydroxamic acid [SAHA]) in patients with advanced leukemias and myelodysplastic syndromes. Blood; 111: 1060-6.

70. Munster, P.N.; Marchion, D.; Thomas, S.; Egorin, M.; Minton, S.; Springett, G.; Lee, J.H.; Simon, G.; Chiappori, A.; Sullivan, D.; Daud, A.(2009): Phase I trial of vorinostat and doxorubicin in solid tumours: histone deacetylase 2 expression as a predictive marker, $\mathrm{Br} \mathrm{J}$ Cancer; 101: $1044-50$ 
71. Mancini, M.L.; Sonis, S.T. (2014): Mechanisms of cellular fibrosis associated with cancer regimen-related toxicities, Front Pharmacol.; 27(5):51.

72. Choi, Y.W.; Munden, R.F.; Erasmus, J.J.; Park, K.J.; Chung, W.K.; Jeon, S.C.; Park, C.K. (2004): Effects of radiation therapy on the lung: Radiologic appearances and differential diagnosis, Radiographics; 24:985997.

Table 1. Mean \pm SD of body weight at the start and end of the experiment in different groups

\begin{tabular}{|c|c|c|c|c|c|c|c|c|}
\hline & & & $\begin{array}{l}\text { Control } \\
\text { (Group I) }\end{array}$ & $\begin{array}{c}\text { HES } \\
\text { (Group II) }\end{array}$ & $\begin{array}{c}\text { TN } \\
\text { (Group III) }\end{array}$ & $\begin{array}{c}\text { DMBA } \\
\text { (Group IV) }\end{array}$ & $\begin{array}{c}\text { HES-DMBA } \\
\text { (Group V) }\end{array}$ & $\begin{array}{l}\text { TN-DMBA } \\
\text { (Group VI) }\end{array}$ \\
\hline & & $\mathbf{N}$ & 12 & 12 & 12 & 12 & 12 & 12 \\
\hline & 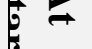 & Range & $105-154$ & $89-130$ & $95-138$ & $100-146$ & $94-147$ & $96-140$ \\
\hline E & & Mean \pm S.D & $129.3 \pm 16.16$ & $108.6 \pm 13.29$ & $117.8 \pm 13.37$ & $\begin{array}{c}122.8 \\
+14.18\end{array}$ & $114.6 \pm 14.67$ & $115.3 \pm 13.76$ \\
\hline$\frac{2}{4}$ & & $\mathbf{N}$ & 12 & 12 & 12 & 6 & 9 & 7 \\
\hline 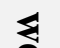 & $\mathbb{D}$ & Range & $170-260$ & $194-284$ & $186-260$ & $122-180$ & $145-215$ & $124-200$ \\
\hline$\stackrel{\mathscr{2}}{0.9}$ & $\vec{n}$ & Mean + S.D & $218.9 \pm 28.5$ & $241.4 \pm 29.74$ & $220.8 \pm 24.19$ & $145.8 \pm 21.5$ & $181 \pm 25.29$ & $159.7 \pm 26.11$ \\
\hline$\stackrel{\text { ᄅ }}{\stackrel{2}{2}}$ & 马. & $P^{(a)}$ value & & 0.005 & 0.819 & $<0.001$ & $<0.001$ & $<0.001$ \\
\hline va & $\overline{2}^{8}$ & $P^{(b)}$ value & & $<0.001$ & $<0.001$ & & 0.001 & 0.204 \\
\hline & & $P^{(\mathbf{c})}$ value & & $<0.001$ & $<0.001$ & & & 0.029 \\
\hline & Percen & ge change & $\uparrow 69.3 \%$ & $\uparrow 122 \%$ & $\uparrow 87.4 \%$ & $\uparrow 18.7 \%$ & $\uparrow 57.6 \%$ & $\uparrow 38.5 \%$ \\
\hline
\end{tabular}

- Significant at $P$ value $\leq 0.05$

- $P^{(\text {a) }}$ value versus control group (group I)

- $P^{(b)}$ value versus DMBA treated group (group IV)

- $P^{(\mathrm{c})}$ value versus HES-DMBA treated group (group V)

(TN)-----Tiger nut - (HES)-----Hesperidin - $\quad$ (DMBA)---7, 12-Dimethylbenz (a) anthracene 
Table 2. Mean + S.D. for rat serum TSA, progesterone and estradiol levels in the different groups

\begin{tabular}{|c|c|c|c|c|c|c|}
\hline $\begin{array}{l}\text { Groups } \\
\text { Parameter }\end{array}$ & $\begin{array}{c}\text { Group I } \\
n=12)(\end{array}$ & $\begin{array}{r}\text { Group II } \\
\text { nn=12( }\end{array}$ & $\begin{array}{c}\text { Group III } \\
(n=12)\end{array}$ & $\begin{array}{c}\text { Group IV } \\
(n=6)\end{array}$ & $\begin{array}{c}\text { Group V } \\
(\mathbf{n}=9)\end{array}$ & $\begin{array}{c}\text { Group VI } \\
(n=7)\end{array}$ \\
\hline $\begin{array}{l}\text { TSA (ng/dl) } \\
\text { (percentage } \\
\text { change) }\end{array}$ & $110 \pm 11.75$ & $\begin{array}{c}112 \pm 18.39^{\mathrm{b}, \mathrm{c}} \\
(\uparrow 1.8 \%)\end{array}$ & $\begin{array}{c}109 \pm 16.10^{\mathrm{b}, \mathrm{c}} \\
(\downarrow 1.87 \%)\end{array}$ & $\begin{array}{c}317 \pm 30.13^{\mathrm{a}} \\
\quad(\uparrow 188 \%)\end{array}$ & $\begin{array}{c}139 \pm \\
14.94^{\mathrm{a}, \mathrm{b}}(\uparrow 26.36 \\
\%) \\
\end{array}$ & $\begin{array}{c}326 \pm 23.13^{\mathrm{a}, \mathrm{c}} \\
(\uparrow 196 \%)\end{array}$ \\
\hline $\begin{array}{l}\text { Estradiol }(\mathrm{pg} / \mathrm{ml}) \\
\text { (percentage } \\
\text { change) }\end{array}$ & $44.08 \pm 11.08$ & $\begin{array}{c}42.17 \pm 10.14 \\
\quad \mathrm{~b}, \mathrm{c}(\downarrow 4.3 \%)\end{array}$ & $\begin{array}{c}41.67 \pm 7.56^{\mathrm{b}, \mathrm{c}} \\
\quad(\downarrow 5.46 \%)\end{array}$ & $\begin{array}{c}105 \pm 18.7^{\mathrm{a}} \\
(\uparrow 138 \%)\end{array}$ & $\begin{array}{c}59.1 \pm 11.24^{\mathrm{a}, \mathrm{b}} \\
(\uparrow 34.07 \%)\end{array}$ & $\begin{array}{c}102 \pm \\
21.06^{\mathrm{a}, \mathrm{c}}(\uparrow 131 \%)\end{array}$ \\
\hline $\begin{array}{l}\text { progesterone } \\
(\mathrm{ng} / \mathrm{ml}) \\
\text { (percentage } \\
\text { change) }\end{array}$ & $15.73 \pm 2.43$ & $\begin{array}{c}15.3 \pm 2.39^{\mathrm{b}, \mathrm{c}} \\
\quad(\downarrow 2.7 \%)\end{array}$ & $\begin{array}{c}16.14 \pm 2.51^{\mathrm{b}, \mathrm{c}} \\
(\uparrow 2.6 \%)\end{array}$ & $\begin{array}{c}33.70 \pm 6.78^{a} \\
(\uparrow 114 \%)\end{array}$ & $\begin{array}{c}22.06 \pm \\
4.25^{\mathrm{a}, \mathrm{b}}(\uparrow 40.24 \%)\end{array}$ & $\begin{array}{c}31.31 \pm 3.85^{\mathrm{a}, \mathrm{c}} \\
\quad(\uparrow 99 \%)\end{array}$ \\
\hline
\end{tabular}

Significant at $P$ value $\leq 0.05, \quad p>0.05$ is considered non-significant (NS).

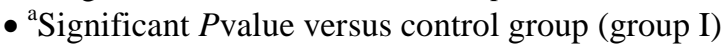

- 'Significant $P$ value versus DMBA treated group (group IV)

- ${ }^{\mathrm{c}}$ Significant $P$ value versus HES-DMBA treated group (group V)

Table 3. Mean + S.D. for the levels of rat serum MDA, CO and GSH and the activity of SOD, CAT and GSH-Px in the different groups

\begin{tabular}{|c|c|c|c|c|c|c|}
\hline $\begin{array}{l}\text { Groups } \\
\text { Parameter }\end{array}$ & $\begin{array}{c}\text { Group I } \\
\mathbf{n}=\mathbf{1 2})(\end{array}$ & $\begin{array}{c}\text { Group II } \\
\mathbf{n}=\mathbf{1 2})(\end{array}$ & $\begin{array}{c}\text { Group III } \\
(\mathrm{n}=12)\end{array}$ & $\begin{array}{c}\text { Group IV } \\
(n=6)\end{array}$ & $\begin{array}{c}\text { Group V } \\
(\mathbf{n}=9)\end{array}$ & $\begin{array}{c}\text { Group VI } \\
(n=7)\end{array}$ \\
\hline $\begin{array}{l}\text { MDA (nmol/ml) } \\
\text { (percentage change) }\end{array}$ & $0.171 \pm 0.038$ & $\begin{array}{c}0.174 \pm 0.033^{\mathrm{b,c}}( \\
\uparrow 1.8 \%)\end{array}$ & $\begin{array}{l}0.177 \pm 0.048^{\mathrm{b}, \mathrm{c}} \\
(\uparrow 3.5 \%)\end{array}$ & $\begin{array}{c}0.579 \pm 0.061^{\mathrm{a}} \\
(\uparrow 238 \%)\end{array}$ & $\begin{array}{c}0.259 \pm 0.072^{\mathrm{a}, \mathrm{b}} \\
(\uparrow 51.5 \%)\end{array}$ & $\begin{array}{l}0.544 \pm 0.095^{\mathrm{a}, \mathrm{c}} \\
(\uparrow 218 \%)\end{array}$ \\
\hline $\begin{array}{l}\mathrm{CO}(\mathrm{nmol} / \mathrm{ml}) \\
\text { (percentage change) }\end{array}$ & $2.31 \pm 0.681$ & $\begin{array}{l}2.39 \pm 0.757^{\mathrm{b}, \mathrm{c}} \\
(\uparrow 3.5 \%)\end{array}$ & $\begin{array}{l}2.20 \pm 0.684^{\mathrm{b}, \mathrm{c}} \\
\quad(\downarrow 4.8 \%)\end{array}$ & $\begin{array}{c}5.69 \pm 0.531^{\mathrm{a}} \\
(\uparrow 146 \%)\end{array}$ & $\begin{array}{c}3.32 \pm 0.438^{\mathrm{a}, \mathrm{b}} \\
(\uparrow 43.7 \%)\end{array}$ & $\begin{array}{c}5.41 \pm 1.01^{\mathrm{a}, \mathrm{c}} \\
(\uparrow 134 \%)\end{array}$ \\
\hline $\begin{array}{l}\text { SOD }(\mathrm{U} / \mathrm{ml}) \\
\text { (percentage change) }\end{array}$ & $129.8 \pm 14.5$ & $\begin{array}{c}134.7 \pm 17.8^{\mathrm{b}, \mathrm{c}} \\
(\uparrow 3.7 \%)\end{array}$ & $\begin{array}{c}135.6 \pm 14.06^{\mathrm{b}, \mathrm{c}} \\
(\uparrow 4.5 \%)\end{array}$ & $\begin{array}{l}20.7 \pm 5.46^{\mathrm{a}} \\
(\downarrow 84 \%)\end{array}$ & $\begin{array}{c}100 \pm 14.36^{\mathrm{a}, \mathrm{b}} \\
(\downarrow 23 \%)\end{array}$ & $\begin{array}{c}21.6 \pm 5.65^{\mathrm{a}, \mathrm{c}} \\
(\downarrow 83.4 \%)\end{array}$ \\
\hline $\begin{array}{l}\text { CAT }(\mathrm{U} / \mathrm{ml}) \\
\text { (percentage change) }\end{array}$ & $5.46 \pm 0.667$ & $\begin{array}{c}5.63 \pm 0.568^{\mathrm{b}, \mathrm{c}} \\
(\uparrow 3.11 \%)\end{array}$ & $\begin{array}{l}5.77 \pm 0.779^{\mathrm{b}, \mathrm{c}} \\
(\uparrow 5.7 \%)\end{array}$ & $\begin{array}{c}2.04 \pm 0.473^{\mathrm{a}} \\
(\downarrow 62.64 \%)\end{array}$ & $\begin{array}{c}4.88 \pm 0.546^{\mathrm{a}, \mathrm{b}} \\
(\downarrow 10.62 \%)\end{array}$ & $\begin{array}{c}2.47 \pm 0.369^{\mathrm{a}, \mathrm{c}} \\
(\downarrow 54.76 \%)\end{array}$ \\
\hline $\begin{array}{l}\text { GSH-Px (mg } \\
\text { consumed } \\
\text { glutathione/min/ml) } \\
\text { (percentage change) }\end{array}$ & $4.90 \pm 0.673$ & $\begin{array}{l}4.92 \pm 0.606^{\mathrm{b}, \mathrm{c}} \\
\quad(\uparrow 0.41 \%)\end{array}$ & $\begin{array}{c}4.68 \pm 0.906^{\mathrm{b}, \mathrm{c}} \\
(\downarrow 4.5 \%)\end{array}$ & $\begin{array}{l}0.014 \pm 0.0039^{\mathrm{a}} \\
(\downarrow 99.7 \%)\end{array}$ & $\begin{array}{l}3.56 \pm 0.564^{\mathrm{a}, \mathrm{b}} \\
\quad(\downarrow 27.3 \%)\end{array}$ & $\begin{array}{c}0.017 \pm 0.0036 \\
\mathrm{a,c}(\downarrow 99.7 \%)\end{array}$ \\
\hline $\begin{array}{l}\text { GSH }(\mathbf{m g} / \mathbf{m l}) \\
\text { (percentage change) }\end{array}$ & $17.31 \pm 1.91$ & $\begin{array}{c}17.37 \pm 2.28^{\mathrm{b}, \mathrm{c}} \\
(\uparrow 0.35 \%)\end{array}$ & $\begin{array}{c}17.37 \pm 1.74^{\mathrm{b}, \mathrm{c}} \\
(\uparrow 0.35 \%)\end{array}$ & $\begin{array}{c}2.14 \pm 0.328^{\mathrm{a}} \\
(\downarrow 87.64 \%)\end{array}$ & $\begin{array}{c}10.58 \pm 1.98^{\mathrm{a}, \mathrm{b}} \\
(\downarrow 38.88 \%)\end{array}$ & $\begin{array}{c}1.38 \pm 0.295^{\mathrm{a}, \mathrm{c}} \\
(\downarrow 92.03 \%)\end{array}$ \\
\hline
\end{tabular}

Significant at $P$ value $\leq 0.05, \quad p>0.05$ is considered non-significant (NS).

- a Significant $P$ value versus control group (group I)

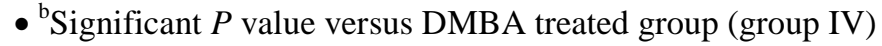

- ${ }^{c}$ Significant $P$ value versus HES-DMBA treated group (group V) 

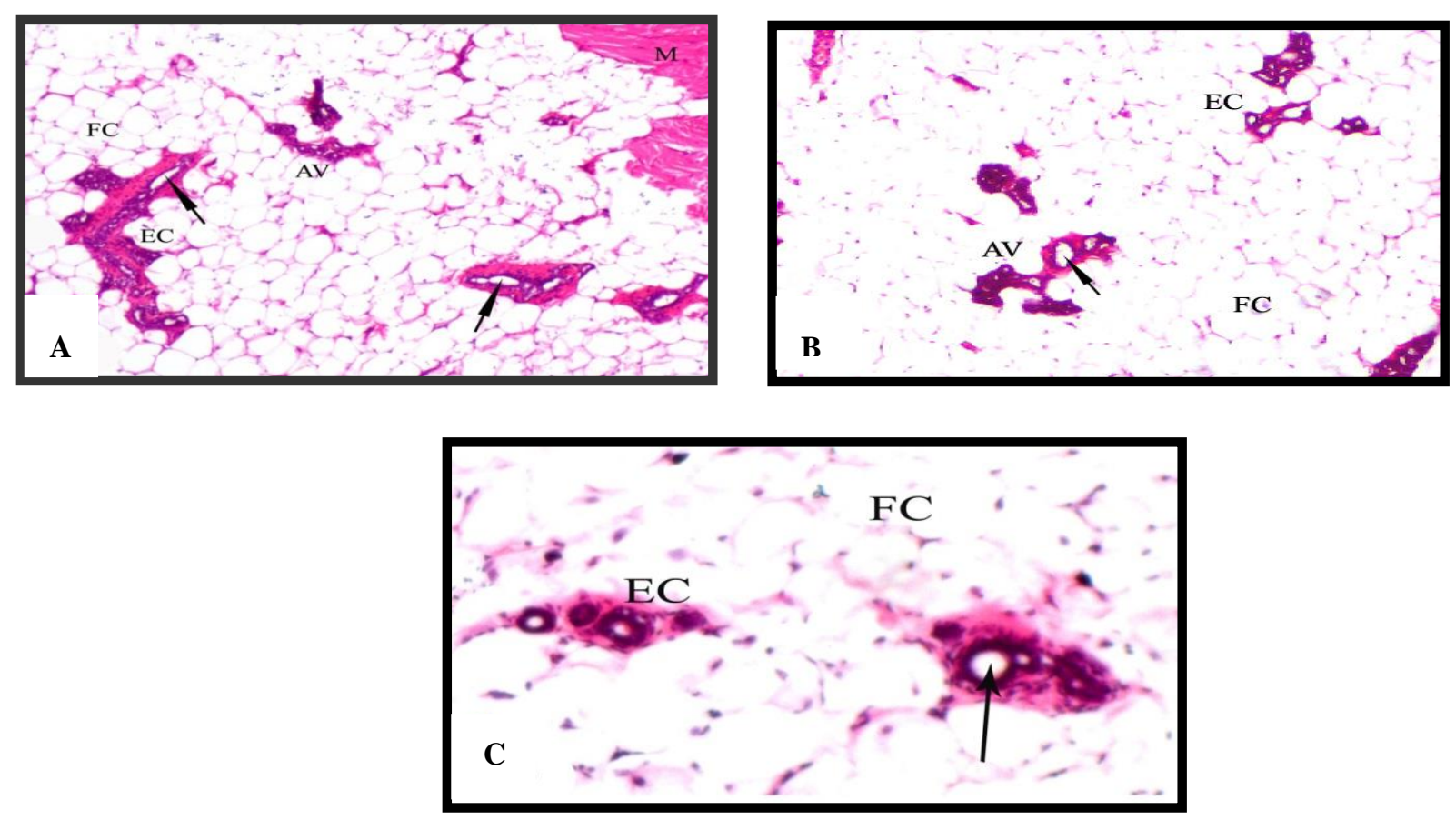

Figure 1(A): Light micrograph showing mammary gland epithelia of control rat that consisting of two layers of epithelial cells (EC) surrounding the lumen (arrow) of the alveoli (AV) embedding in adipose tissue (fat cell FC). Note the presence of muscle part (M). Haematoxylin and eosin (H\&E X 200).(B): Light micrograph showing mammary gland epithelia of HES treated group (H\&E X 200).(C): Light micrograph showing mammary gland epithelia of TN receiving rat (H\&E X 400).

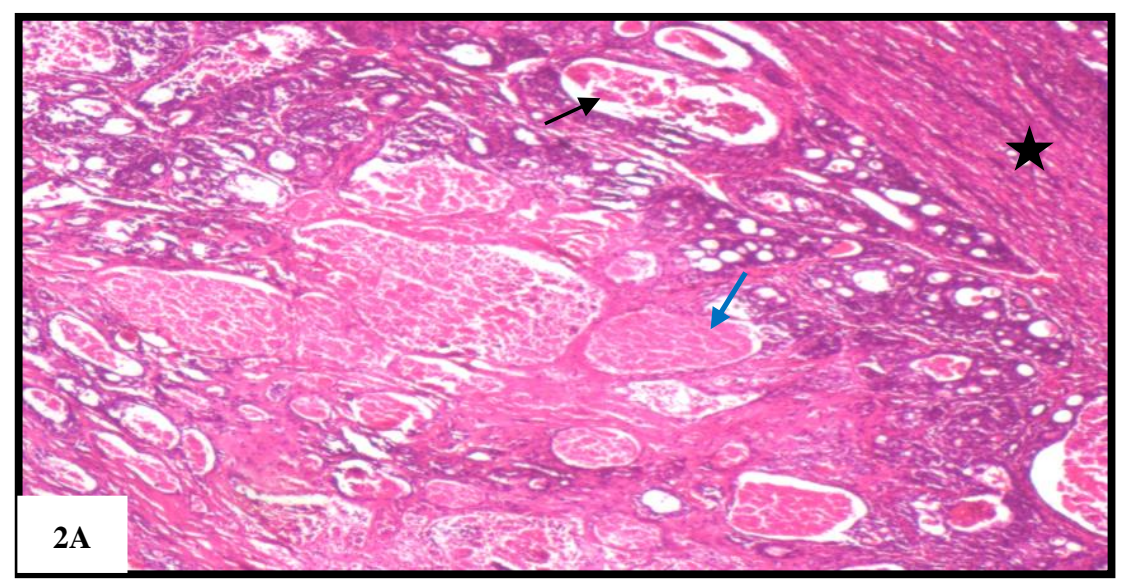

Figure 2 (A): Light micrograph of breast cancer tissue showing wide areas of necrosis and tumor breakdown indicating the high proliferation of tumor cells with surrounding residual viable proliferating malignant cells (black arrow), Note the presence of dead cells (blue arrow) and neoplastic cells invasive feature ( $\downarrow$ ). (H\&E X 200). 


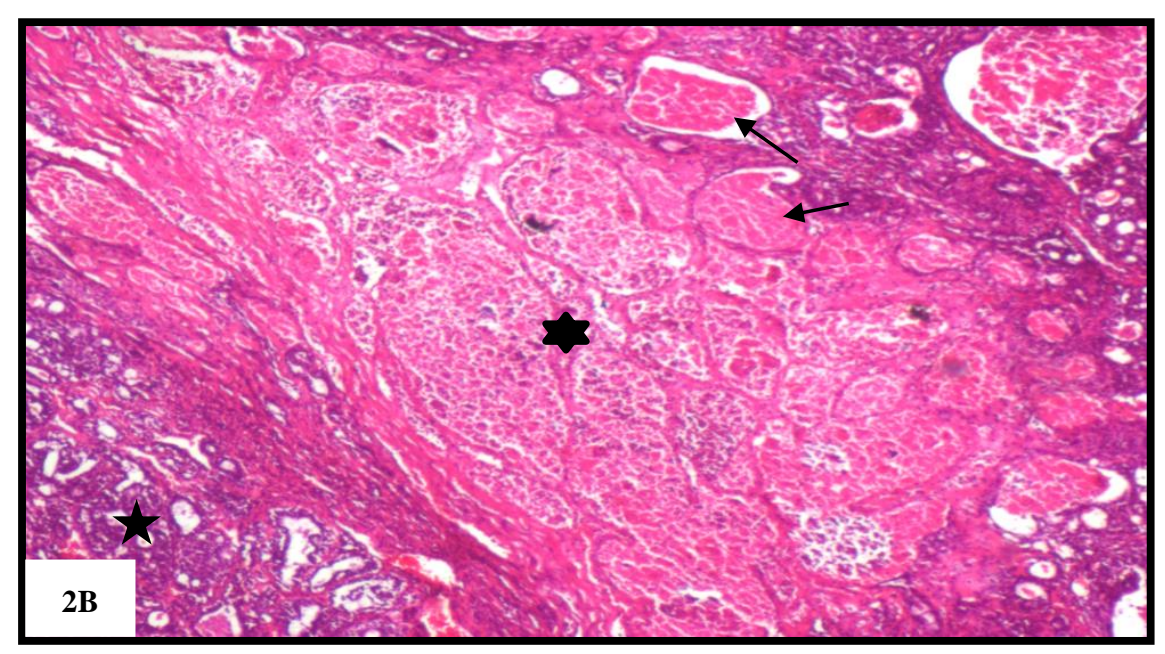

Figure 2 (B): Light micrograph of a section of breast tumor arising in rat breast receiving DMBA showing atypical proliferative changes characterized by a progressive elongation of ducts as well as proliferation and expansion of the terminal lobular units (HLU)() with compression of the surrounding fat pad, progressing to cystic papillary carcinoma $(\mathrm{CA})(\boldsymbol{\lambda})$ (H\&E X 200). Note the presence of dead cells (arrow).
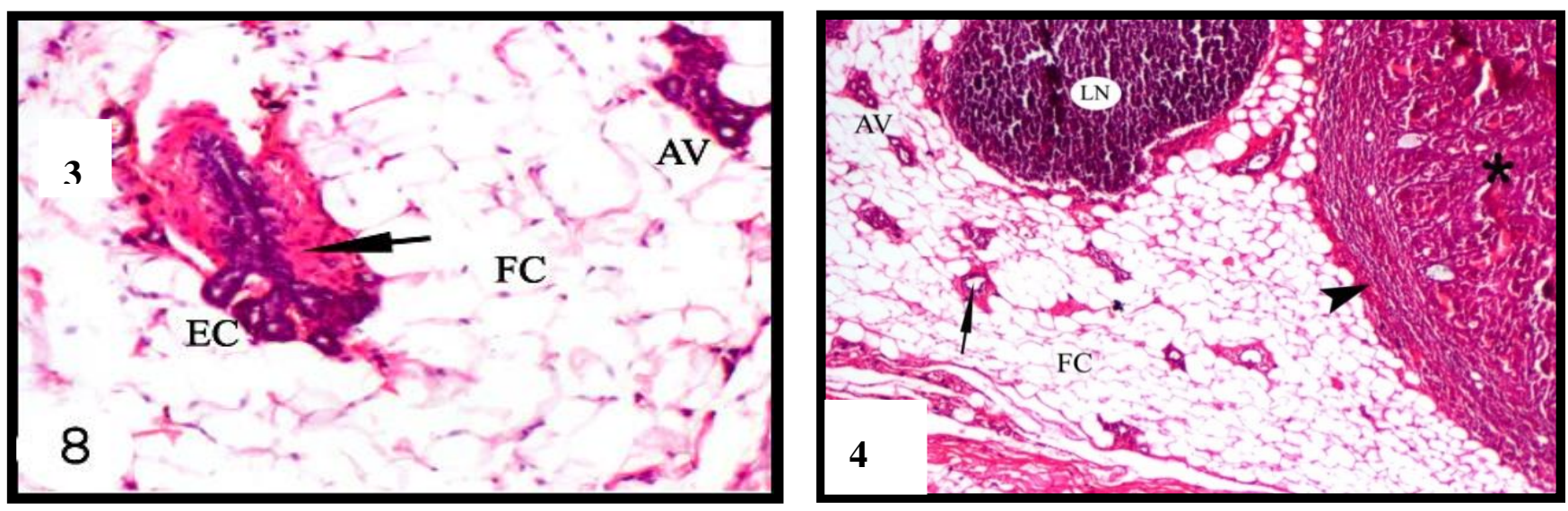

Figure 3: Light micrograph showing mammary gland epithelia of HES-DMBA treated rat that consisting of two layers of epithelial cells (EC) surrounding the lumen (L) of the alveoli (AV), surrounded by thick basement membrane (arrow) and embedded in adipose tissue (fat cell FC). (H\&E X 400).

Figure 4:Light micrograph showing mammary gland of TN-DMBA treated rat that showing well defined mass of breast carcinoma that surrounded by fibrous tissue (arrowhead) embedded in fat cells (FC) with adjacent enlarged activated lymph node (LN). (H\&E X100). 